\title{
O INDIVIDUAL E O COLETIVO NO TRABALHO POR PLATA- FORMAS DIGITAIS: POSSIBILIDADES DE COMPREENSÃO DA CONSTITUIÇÃO A PARTIR DA EXPERIÊNCIA DO “BRE- QUE DOS APPS"
}

THE INDIVIDUAL AND THE COLLECTIVE IN THE DIGITAL WORK PLATFORMS: POSSIBILITIES FOR UNDERSTANDIG THE CONSTITUTION FROM THE EXPERIENCE OF THE "BREQUE DOS APPS"

RICARDO LOURENÇO FILHO*

RESUMO

O "breque dos apps", realizado em julho de 2020, se destacou por aspectos como a tentativa de superação, pelos trabalhadores, dos desafios postos pela gestão empresarial por algoritmos e a visibilidade conferida aos coletivos de entregadores. Mas também explicitou dilemas, como os atinentes à própria denominação do movimento e à classificação jurídica das relações laborais por aplicativos digitais. De toda forma, a experiência dessa mobilização permite afirmar que o debate sobre a regulação estatal do trabaIho por plataformas digitais deve considerar as perspectivas e os riscos correspondentes nos planos individual e coletivo, em especial, quanto a esse último, no que diz respeito às dimensões da liberdade sindical, da negociação coletiva e da greve. A reivindicação e o exercício, por parte dos entregadores por plataformas digitais, de direitos fundados na Constituição têm o condão de indicar novas possibilidades de interpretação jurídica e efetivação do texto constitucional. Também podem servir para viabilizar a participação desses trabalhadores na discussão pública sobre a regulação jurídica do labor por aplicativos, assim como em outros espaços de debates que envolvam direitos fundamentais.

Palavras-chave: Trabalho por plataformas digitais; "breque dos apps"; regulação jurídica; direitos coletivos; Constituição.

\section{ABSTRACT}

The "breque dos apps", carried out in July 2020, stood out for aspects such as the workers' attempt to overcome the challenges posed by algorithms based business management and the visibility given to the collectives of couriers. However, it also explained dilemmas such as those related to the denomination itself of the movement and the legal classification of labour relations by digital apps. Anyway, the experience of this mobilization allows us to affirm that the debate on the state regulation of digital work platforms must consider the perspectives and the corresponding risks at the individual and collective levels, especially regarding the latter, with respect to the dimensions of union freedom, collective bargaining and strike. The claim and the exercise, by the couriers by digital platforms, of rights based on the Constitution, have the ability to indicate new possibilities of legal interpretation and effectuation of the constitutional text. They can also serve to enable the participation of these workers in the public discussion on the legal regulation of work by apps, as well as in other spaces for debates involving fundamental rights.

Keywords: Digital work platforms; "breque dos apps"; legal regulation; collective rights; Constitution.

* Doutor e Mestre em Direito, Estado e Constituição pela Universidade de Brasília (UnB).

Professor do Instituto Brasiliense de Direito Público (IDP). Juiz do Trabalho. Integrante do Grupo de Pesquisa

"Percursos, Narrativas, Fragmentos: História do Direito e do Constitucionalismo" (CNPq/UnB) ricardo.lourencofilho@gmail.com 


\author{
INTRODUÇÃO; 1 CARACTERÍSTICAS DO TRABALHO POR PLATAFORMAS DIGITAIS E DESAFIOS À \\ ORGANIZAÇÃO COLETIVA E SINDICAL; 20 "BREQUE DOS APPS" E OS DILEMAS DA MOBILIZAÇÃO \\ COLETIVA DOS TRABALHADORES DE PLATAFORMAS DIGITAIS DE ENTREGA; 3 O MOVIMENTO \\ COLETIVO DOS TRABALHADORES DE PLATAFORMAS DIGITAIS: PERSPECTIVAS E RISCOS \\ PERANTE O DIREITO E A CONSTITUIÇÃO; CONSIDERAÇÕES FINAIS; REFERÊNCIAS.
}

\title{
INTRODUÇÃO
}

O trabalho realizado por plataformas digitais tem colocado algumas questões relevantes ao Direito e, particularmente, ao Direito do Trabalho. A mais frequente é se haveria ou não vínculo de emprego em relações laborais por aplicativos, como as que se desenvolvem pelas plataformas Uber, iFood, Loggi, entre outras. Discute-se, na mesma linha de raciocínio, qual regulação jurídica deve ser conferida pelo Estado para essas relações de trabalho. A ênfase, no debate, é, usualmente, o plano individual, isto é, o liame existente entre o prestador de serviço e a plataforma.

Ocorrido em julho de 2020, no contexto da pandemia decorrente do novo coronavírus e da implementação de medidas de isolamento social, ${ }^{1}$ o "breque dos apps" chamou a atenção para o plano coletivo do labor executado por aplicativos, ao reunir, de forma presencial e virtual (pelas redes sociais), inúmeros trabalhadores de plataformas digitais de entrega de produtos. Foram apresentadas aos aplicativos e à sociedade em geral reivindicações que refletiam a realidade de serviço desses trabalhadores. A mobilização coletiva ampliou o leque de perguntas dirigidas ao Direito do Trabalho, inclusive para além do tema da existência ou não de vínculo empregatício.

Este artigo pretende se debruçar sobre as questões jurídicas postas no plano coletivo das relações de trabalho por plataformas digitais, partindo da experiência do "breque dos apps", no que diz respeito às dimensões fundamentais da liberdade sindical, da negociação coletiva e da greve. A premissa aqui é a de que a discussão sobre a regulação estatal do trabalho por aplicativos deve considerar, de modo relacional, os planos individual e coletivo. Ao abordar os riscos da incorporação do labor por plataformas digitais segundo os padrões do Direito do Trabalho, em especial quanto à organização coletiva desses trabalhadores, o texto busca possíveis respostas na Constituição e na prática concreta de direitos constitucionais evidenciada no "breque dos apps".

\footnotetext{
${ }^{1}$ Em 30 de janeiro de 2020, a Organização Mundial da Saúde (OMS) apresentou Declaração de Emergência em Saúde Pública de Importância Internacional e, em 11 de março do mesmo, formulou declaração pública de pandemia quanto ao novo coronavírus, causador da enfermidade Covid-19. No Brasil, a Câmara dos Deputados e, na sequência, o Senado Federal aprovaram a Mensagem Presidencial no 93/2020, quanto ao reconhecimento do estado de calamidade pública no país. A Lei no 13.979/2020 dispôs sobre as medidas para enfrentamento da emergência de saúde pública de importância internacional, prevendo, entre outras providências, as possibilidades de isolamento e quarentena (art. 3으, I e II).
} 
O pressuposto teórico alinha-se à compreensão da Constituição como um "texto responsivo", ao qual se dirige para procurar respostas e que é tratado como ponto de chegada e de convergência do pluralismo político e social. A Constituição é observada a partir da realidade, e não o contrário. Com efeito, a legitimidade do texto constitucional relaciona-se à sua capacidade de oferecer respostas adequadas, ou, de forma mais específica, à capacidade do direito constitucional de encontrar tais respostas na Constituição. ${ }^{2}$

Há, nesse sentido, uma preocupação com a concretização dos direitos fundamentais, tendo em vista que as normas constitucionais de princípio garantidoras desses direitos apontam uma direção e vinculam o futuro, ${ }^{3}$ o que inclui servir de parâmetro para as decisões a serem tomadas pelas instâncias estatais, abrangidos o Legislativo e o Judiciário, e também para a atuação dos cidadãos. A Constituição, assim, é compreendida como a moldura de um processo permanente de conquista e exercício de direitos fundamentais. ${ }^{4}$

O artigo objetiva, então, apresentar possibilidades de compreensão e uso do texto constitucional, no que tange à organização coletiva dos trabalhadores por plataformas digitais, com potenciais reflexos na discussão sobre a regulação jurídico-estatal desse labor no e mesmo em outras pautas sobre direitos fundamentais.

O texto está dividido em três partes. A primeira examina as características do trabaIho por aplicativos, marcado pelo uso de tecnologias digitais como forma de gestão empresarial, e os desafios colocados à organização coletiva e sindical. A segunda analisa o "breque dos apps" e as ações coletivas dos trabalhadores de plataformas de entrega, destacando alguns dilemas do movimento. A terceira se volta às perspectivas e aos riscos, nos planos individual e coletivo, da normalização jurídica do labor por aplicativos digitais e sinaliza possíveis respostas a partir da Constituição e da articulação de demandas que encontram amparo no texto constitucional.

\section{CARACTERÍSTICAS DO TRABALHO POR PLATAFORMAS DIGITAIS E DESAFIOS À ORGANIZA- ÇÃO COLETIVA E SINDICAL}

Diversas expressões têm sido utilizadas para designar o trabalho prestado por plataformas digitais. Entre elas, temos gig-economy, platform economy, sharing economy, crowdsourcing, on-demand economy, uberização, crowdwork, trabalho digital. Essa nomenclatura diz respeito a formas de trabalho que possuem características comuns, como o estabelecimento de contatos on-line, por meio de aplicativos ou plataformas digitais, entre trabaIhadores e empresas e produtores e consumidores; o uso de tecnologias digitais para a organização e a gestão das atividades assim prestadas; e relações firmadas por demanda. ${ }^{5}$

\footnotetext{
2 Ver ZAGREBELSKY, Gustavo. Historia y constitución. Tradução de Miguel Carbonell. Madrid: Minima Trotta, 2005, p. 81-82.

${ }^{3}$ Cf. ZAGREBELSKY, Gustavo. Historia y constitución. Tradução de Miguel Carbonell. Madrid: Minima Trotta, 2005, p. 89.

${ }^{4}$ Ver CARVALHO NETTO, Menelick. "A hermenêutica constitucional e os desafios postos aos direitos fundamentais". SAMPAIO, José Adércio Leite (Org.). Jurisdição Constitucional e Direitos Fundamentais. Belo Horizonte: Del Rey, 2003, p. 141-163 (p. 154).

${ }^{5}$ Ver ANTUNES, Ricardo; FILGUEIRAS, Vitor. "Plataformas digitais, Uberização do trabalho e regulação no Capitalismo contemporâneo". Contracampo, Niterói, v. 39, n. 1, abr./jul. 2020, p. 27-43 (p. 31).
} 
O Individual e o Coletivo no trabalho por plataformas digitais: possibilidades de compreensão da Constituição a partir da experiência do "breque dos apps"

Contudo, as plataformas digitais (e os trabalhos realizados por meio delas) não têm as mesmas características. Certas plataformas atuam como simples intermediárias, mediante a viabilização de contato entre trabalhadores e interessados em determinado serviço, sem que a plataforma estipule preço, qualidade, quantidade, condições, etc. Há, no entanto, plataformas que assumem o papel de protagonistas da relação e garantem a qualidade do serviço prestado, por meio da fixação de condições de execução das tarefas, definição de preço da atividade e remuneração da pessoa que realiza o serviço. Assim, quem consume o trabalho ofertado torna-se cliente da plataforma digital, e não da pessoa que executa a tarefa. No primeiro grupo, tem-se, por exemplo, o Mercado Livre; já no segundo, tem-se, entre outros, a Uber e o iFood. ${ }^{6}$

Oliveira, Carelli e Grillo propõem a seguinte conceituação para as plataformas digitais de trabalho:

modelos de negócio baseados em infraestruturas digitais que possibilitam a interação de dois ou mais grupos tendo como objeto principal o trabalho intensivo, sempre considerando como plataforma não a natureza do serviço prestado pela empresa, mas sim o método, exclusivo ou conjugado, para a realização do negócio empresarial. $^{7}$

A definição proposta acima tem a virtude de destacar que o aspecto decisivo não é a atividade em si oferecida pela plataforma (como o transporte ou a entrega), e, sim, a forma de exploração da empresa, fundada em tecnologias digitais para sua organização e gestão. Os autores sugerem classificar as plataformas em puras (aquelas que não efetuam "controle relevante" sobre a interação entre os negociantes) e mistas ou híbridas (aquelas em que há uma mistura "entre mercado e hierarquia" e "a forma empresarial de plataforma serve à prestação final de um serviço que com ela não se confunde"). ${ }^{8}$

Ao desenvolver o conceito de uberização do trabalho, Ludmila Abílio também enfatiza que se trata de uma nova forma de gestão, organização e controle do labor. Lembra, porém, que se cuida do resultado de "processos globais em curso há décadas". ${ }^{9}$

Para resgatar os exemplos mencionados, a Uber oferece o serviço em nome próprio, como se constata, entre outras evidências, pelo fato de que as opções de viagens "mais populares" levam a marca da empresa, como a "UberX" e a "Uber Comfort". ${ }^{10}$ Também o iFood se apresenta no mercado como o titular de um serviço, como consta de seu site, relativamente

\footnotetext{
${ }^{6}$ Cf. CARELLI, Rodrigo. "O trabalho em plataformas e o vínculo de emprego: desfazendo mitos e mostrando a nudez do rei". CARELLI, Rodrigo de Lacerda; CAVALCANTI, Tiago Muniz; FONSECA, Vanessa Patriota da (org.). Futuro do Trabalho: os efeitos da revolução digital na sociedade. Brasília, ESMPU, 2020), p. 65-83.

7 OLIVEIRA, Murilo Carvalho Sampaio; CARELLI, Rodrigo de Lacerda; GRILLO, Sayonara. "Conceito e crítica das plataformas digitais de trabalho". Revista Direito e Práxis. Rio de Janeiro, v. 11, n. 4, 2020, p. 2609-2634 (p. 2622 ). ${ }^{8}$ OLIVEIRA, Murilo Carvalho Sampaio; CARELLI, Rodrigo de Lacerda; GRILLO, Sayonara. "Conceito e crítica das plataformas digitais de trabalho". Revista Direito e Práxis. Rio de Janeiro, v. 11, n. 4, 2020, p. 2609-2634 (p. 2622 ). ${ }^{9}$ ABÍLIO, Ludmila Costhek. "Uberização: Do empreendedorismo para o autogerenciamento subordinado". Psicoperspectivas, vol. 18, n. 3, novembro 2019, p. 1-11 (p. 2).

${ }^{10}$ Disponível em https://www.uber.com/br/pt-br/about/uber-offerings/ Acesso em 30.11.2020.
} 
às entregas: "nunca foi tão fácil pedir comida japonesa", por exemplo. ${ }^{11} \mathrm{Em}$ ambos os casos, destacam-se a gestão e a organização de uma atividade empresarial por meio de tecnologia digital. Nas duas plataformas mencionadas, é possível identificar a característica apontada por Oliveira, Carelli e Grillo: a interação oferecida pela plataforma não é a sua finalidade, mas o meio para o oferecimento de um serviço (o transporte ou a entrega).

Para os fins desta pesquisa, é interessante, partindo dos conceitos acima, examinar o trabalho prestado por meio das plataformas digitais que se apresentam como titulares de um serviço específico (que não se confunde com a própria plataforma em si) e definem aos trabalhadores como esse serviço deve ser prestado - como é o caso, de modo exemplificativo, da Uber e do iFood.

O discurso das plataformas digitais é o de que os trabalhadores realizam as atividades quando querem e onde querem, pois não há um compromisso, formalizado, que garanta a continuidade do trabalho. Também afirmam a criação de um ambiente laboral mais atrativo, por meio de plataformas e aplicativos, para diferentes estilos de vida, "sem a rigidez dos empregos tradicionais"; ou, então, de que se trata de uma renda extra ou uma forma de obter dinheiro no tempo livre. ${ }^{12}$

O uso da tecnologia é, com frequência, apresentado como um motivo para que as atividades por plataformas digitais sejam tratadas como novas formas de trabalho, diferentes das demais existentes no mercado e, assim, seria inadequada sua regulação de acordo com os padrões do Direito, em particular do Direito do Trabalho. O pressuposto desse discurso é o de que as pessoas que trabalham por plataformas eletrônicas não teriam vínculo de emprego e, desse modo, não careceriam da proteção jurídica correspondente. ${ }^{13}$

A estratégia das plataformas digitais é a negação da relação de emprego e das garantias jurídicas respectivas. Essa estratégia empresarial é fundamental e tem a função de vender uma aparência de autonomia que permite às empresas ampliar o controle e a exploração sobre o trabalho. ${ }^{14}$

A retórica comum é a de que seriam meras empresas de tecnologia ou de intermediação tecnológica, mas não de organização de uma atividade, como transporte ou entrega de produtos. ${ }^{15}$ Entretanto, como apontado acima, é um argumento que não se sustenta quando

\footnotetext{
${ }^{11}$ Disponível em https://www.ifood.com.br/ Acesso em 30.11.2020. Na página destinada aos "parceiros", isto é, restaurantes e mercados, vê-se que a garantia vem da própria plataforma digital: "venda mais com o iFood clientes a um clique de distância e seu negócio vendendo como nunca" (Disponível em https://parceiros.ifood.com.br/ Acesso em 30.11.2020).

${ }^{12}$ Cf ANTUNES, Ricardo; FILGUEIRAS, Vitor. "Plataformas digitais, Uberização do trabalho e regulação no Capitalismo contemporâneo". Contracampo, Niterói, v. 39, n. 1, abr./jul. 2020, p. 27-43 (p. 31).

${ }^{13}$ Ver DE STEFANO, Valerio. "Labour is not a technology - Reasserting the Declaration of Philadelphia in times of platform-work and gig-economy". IUSLabor 2/2017, p. 1-17 (p. 3).

${ }^{14}$ Como observam Ricardo Antunes e Vitor Filgueiras: "a negação do assalariamento é elemento central da estratégia empresarial, pois, sob a aparência de maior autonomia (eufemismo para burlar o assalariamento e efetivar a transferência dos riscos), o capital busca, de fato, ampliar o controle sobre o trabalho para recrudescer a exploração e sua sujeição" (ANTUNES, Ricardo; e FILGUEIRAS, Vitor. "Plataformas digitais, Uberização do trabaIho e regulação no Capitalismo contemporâneo", p. 29).

${ }^{15}$ Cf. CARDOSO, Ana Claudia Moreira; ARTUR, Karen; OLIVEIRA, Murilo Carvalho Sampaio. "O trabalho nas plataformas digitais: narrativas contrapostas de autonomia, subordinação, liberdade e dependência". Revista Valore, Volta Redonda, 5, 2020, p. 206-230 (p. 209).
} 
O Individual e o Coletivo no trabalho por plataformas digitais: possibilidades de compreensão da Constituição a partir da experiência do "breque dos apps"

se observa o fato de que se trata de uma forma específica de gestão e organização empresarial. Assim, as plataformas digitais não compreendem um novo e específico setor, mas se inserem no mesmo ramo do serviço executado. ${ }^{16}$

Os instrumentos tecnológicos permitem ampliar as formas de controle sobre a força laboral, o que contraria o discurso de autonomia vendido aos trabalhadores pelas plataformas digitais. É aqui que se coloca um dos principais desafios ao Direito do Trabalho. Muitas vezes, a noção de subordinação jurídica (extraída da expressão "dependência", do art. 3o da CLT) é aplicada de modo tão restritivo que não se concebe nenhum espaço de liberdade ao empregado, submetido, de modo praticamente absoluto, ao poder diretivo do empregador. Porém, com relação ao trabalho realizado por plataformas digitais, o poder de direção e gestão da empresa - e, portanto, a condição de subordinação/dependência do trabalhador - é encoberto pelas tecnologias de comunicação e informação. ${ }^{17}$

O poder diretivo do empregador, na forma do art. 2으 da CLT, se manifesta sobretudo por meio do sistema, do software, do aplicativo, do código-fonte ou do algoritmo que define a organização e o modo de oferecimento do serviço. As regras do negócio e da realização do trabalho são definidas pelo algoritmo, pelo código-fonte, pelo aplicativo, e não por meras cláusulas contratuais. ${ }^{18}$

Como apontam Ricardo Antunes e Vitor Filgueiras, a principal novidade presente na organização laboral por meio das novas tecnologias de informação e comunicação, a par de potencializar, de forma exponencial, os meios de obtenção de lucros e de extração da mais valia, é viabilizar às empresas a utilização desses instrumentos digitais para o controle da força de trabalho, como, por exemplo, o acompanhamento, em tempo real, da realização da tarefa, da velocidade, do local e do deslocamento realizados, das avaliações, etc. Todo esse controle é exercido pelo comando dos algoritmos. ${ }^{19}$

Segundo aqueles autores, o fetiche "do mundo tecnológico do capital" conduz à ampliação de outro fetiche: o de que tudo é impulsionado por uma tecnologia neutra e autônoma. Ocorre que o comando do algoritmo pertence à engenharia de informações do capital, que, por conseguinte, tem também o controle do trabalho individual (incluindo ritmo, tempo,

\footnotetext{
${ }^{16}$ Ver OLIVEIRA, Murilo Carvalho Sampaio; CARELLI, Rodrigo de Lacerda; GRILLO, Sayonara. "Conceito e crítica das plataformas digitais de trabalho". Revista Direito e Práxis. Rio de Janeiro, v. 11, n. 4, 2020, p. $2609-2634$ (p. 2622). Cf. também DE STEFANO, Valerio. "Labour is not a technology - Reasserting the Declaration of Philadelphia in times of platform-work and gig-economy". IUSLabor 2/2017.

${ }^{17}$ Ver CHAVES JÚNIOR, José Eduardo de Resende. "O Direito do Trabalho e as Plataformas Eletrônicas". MELO, Raimundo Simão de; ROCHA, Cláudio Jannoti. Constitucionalismo, trabalho, seguridade social e as reformas trabalhista e previdenciária. São Paulo: LTr, 2017, p. 357-366.

${ }^{18}$ Cf. CHAVES JÚNIOR, José Eduardo de Resende. "O Direito do Trabalho e as Plataformas Eletrônicas". MELO, Raimundo Simão de; ROCHA, Cláudio Jannoti. Constitucionalismo, trabalho, seguridade social e as reformas trabalhista e previdenciária. São Paulo: LTr, 2017. Ludmila Abílio aponta, ainda, como centrais para a constatação da subordinação e do controle sobre o trabalho: “i) é a empresa que define para o consumidor o valor do serviço que o trabalhador oferece, assim como o quanto o trabalhador recebe e, não menos importante, ii) a empresa detém total controle sobre a distribuição do trabalho, assim como sobre a determinação e utilização das regras que definem essa distribuição" (ABÍLIO, Ludmila Costhek. "Uberização: Do empreendedorismo para o autogerenciamento subordinado". Psicoperspectivas, vol. 18, n. 3, novembro 2019, p. 3).

${ }^{19}$ Ver ANTUNES, Ricardo; FILGUEIRAS, Vitor. "Plataformas digitais, Uberização do trabalho e regulação no Capitalismo contemporâneo". Contracampo, Niterói, v. 39, n. 1, abr./jul. 2020, p. 33.
} 
eficiência, produtividade). ${ }^{20} \mathrm{O}$ que é defendido, pelas empresas, como liberdade e flexibilidade corresponde, de fato, à transferência dos riscos da atividade econômica à força de trabalho, e a contrapartida dessa transferência é o incremento do controle sobre os trabalhadores. Afinal, a suposta liberdade corresponde à falta de garantia de um salário e ao aumento de custos fixos. ${ }^{21}$

A incerteza quanto às condições (em especial, quantidade e qualidade) de execução das atividades submete os trabalhadores a um sistema de gestão denominado gamificação, que vem da palavra em inglês game, como explica Ludmila Abílio:

Esse é um termo que expressa a operacionalidade de regras cambiantes que tornam o engajamento no trabalho arriscado e sem garantias. A produtividade é estimulada e conquistada por meio de regras que se apresentam como desafios para o trabalhador, que envolvem premiações e, principalmente, a incerteza de se alcançar o resultado perseguido. ${ }^{22}$

A gestão gamificada leva os trabalhadores a permanecerem disponíveis, em busca de corridas ou entregas, mas sem recebimento do tempo de espera, porque são chamados apenas quando necessário e remunerados de forma correspondente. A estipulação unilateral, pelas plataformas digitais, dos valores dos serviços e a manipulação desses valores funcionam para dirigir e direcionar, por meio dos algoritmos, a conduta dos trabalhadores. As baixas remunerações fazem com que um contingente expressivo de prestadores esteja continuamente pronto para o serviço, mesmo diante de valores reduzidos. Os trabalhadores se veem, então, num leilão invertido, que os coloca em condição de permanente competição entre si. ${ }^{23}$

A rejeição do status de trabalhador assalariado e das proteções jurídicas previstas no ordenamento leva a uma situação de precarização, marcada, entre outros aspectos, por longas jornadas e baixas remunerações. É uma dinâmica que impulsiona a competitividade entre os trabalhadores. Trata-se de lógica coerente com o neoliberalismo e a imagem de que os trabalhadores seriam empreendedores, ${ }^{24}$ imagem essa que opera como técnica para a criação de subjetividades "assentadas no individualismo e na concorrência". ${ }^{25}$

\footnotetext{
${ }^{20}$ Cf. ANTUNES, Ricardo; FILGUEIRAS, Vitor. "Plataformas digitais, Uberização do trabalho e regulação no Capitalismo contemporâneo". Contracampo, Niterói, v. 39, n. 1, abr./jul. 2020, p. 33.

${ }^{21}$ Ver ANTUNES, Ricardo; FILGUEIRAS, Vitor. "Plataformas digitais, Uberização do trabalho e regulação no Capitalismo contemporâneo". Contracampo, Niterói, v. 39, n. 1, abr./jul. 2020, p. 33.

${ }^{22}$ ABÍLIO, Ludmila Costhek. "Uberização: Do empreendedorismo para o autogerenciamento subordinado". Psicoperspectivas, vol. 18, n. 3, novembro 2019, p. 1-11 (p. 3).

${ }^{23}$ Cf. ANTUNES, Ricardo; FILGUEIRAS, Vitor. "Plataformas digitais, Uberização do trabalho e regulação no Capitalismo contemporâneo". Contracampo, Niterói, v. 39, n. 1, abr./jul. 2020, p. 33-34.

${ }^{24}$ Segundo Ludmila Abílio, "o empreendedorismo torna-se genericamente sinônimo de assumir riscos da própria atividade. Opera aí um importante deslocamento do desemprego enquanto questão social para uma atribuição ao indivíduo da responsabilização por sua sobrevivência em um contexto de incerteza e precariedade" (ABÍLIO, Ludmila Costhek. "Uberização: Do empreendedorismo para o autogerenciamento subordinado". Psicoperspectivas, vol. 18, n. 3, novembro 2019, p. 4).

${ }^{25}$ OLIVEIRA, Murilo Carvalho Sampaio; CARELLI, Rodrigo de Lacerda; GRILLO, Sayonara. "Conceito e crítica das plataformas digitais de trabalho". Revista Direito e Práxis. Rio de Janeiro, v. 11, n. 4, 2020, p. 2611.
} 
O Individual e o Coletivo no trabalho por plataformas digitais: possibilidades de compreensão da Constituição a partir da experiência do "breque dos apps"

As plataformas digitais encerram "novas formas de dispersar o trabalho sem perder o controle sobre ele". ${ }^{26}$ São modelos de estruturação do labor que reforçam a dimensão individual, estabelecem sistemas de competição entre os próprios trabalhadores e incentivam comportamentos de autoexploração. E contêm a marca do discurso neoliberal para o mercado de trabalho ${ }^{27}$ e das técnicas que servem à fabricação do "sujeito empresarial" e da "cultura da empresa", como explicam Dardot e Laval:

(...) a racionalidade neoliberal produz o sujeito de que necessita ordenando os meios de governá-lo para que ele se conduza realmente como uma entidade em competição e que, por isso, deve maximizar seus resultados, expondo-se a riscos e assumindo inteira responsabilidade por eventuais fracassos.

(...) a novidade consiste em promover uma "reação em cadeia", produzindo "sujeitos empreendedores" que, por sua vez, reproduzirão, ampliarão e reforçarão as relações de competição entre eles, o que exigirá, segundo a lógica do processo autorrealizador, que eles se adaptem subjetivamente às condições cada vez mais duras que eles mesmos produziram. ${ }^{28}$

Essa racionalidade se mostra mais acentuada no âmbito do labor por plataformas digitais, onde impera uma dinâmica contrária à ideia de solidariedade e de ação coletiva, que surge, por sua vez, como algo improvável, com dificuldades ainda maiores do que as identificadas na gestão empresarial toyotista. ${ }^{29}$

As características acima permitem, portanto, evidenciar alguns desafios à organização coletiva e sindical dessa força de trabalho. É um dos motivos pelos quais a mobilização dos entregadores por aplicativos adquiriu uma dimensão tão relevante, como será visto a seguir.

\section{0 "BREQUE DOS APPS" E OS DILEMAS DA MOBILIZAÇÃO COLETIVA DOS TRABALHADORES DE PLATAFORMAS DIGITAIS DE ENTREGA}

Em julho de 2020, durante a pandemia decorrente do novo coronavírus, causador da doença Covid-19, no curso da qual em diversas cidades brasileiras (e no mundo) houve fechamento de estabelecimentos comerciais e de serviços, públicos e privados, e em que parte significativa da população se viu impedida de sair às ruas, foram realizados dois movimentos coletivos dos trabalhadores de aplicativos digitais de entrega. A mobilização se desenvolveu com organização de piquetes e moto-carreatas. Houve trabalhadores que preferiram simples-

\footnotetext{
${ }^{26}$ ABÍLIO, Ludmila Costhek. "Uberização: Do empreendedorismo para o autogerenciamento subordinado". Psicoperspectivas, vol. 18, n. 3, novembro 2019 p. 2.

${ }^{27}$ Discurso que esteve presente na reforma trabalhista de 2017. Cf., a respeito, ARAÚJO, Maurício Azevedo de; DUTRA, Renata Queiroz; JESUS, Selma Cristina Silva de. "Neoliberalismo e flexibilização da legislação trabalhista no Brasil e na França". Revista do Direito. Trabalho e Processo. № 2, abril 2018, pp. 1-24.

${ }^{28}$ DARDOT, Pierre; LAVAL. A nova razão do mundo: ensaio sobre a sociedade neoliberal. Tradução de Mariana Echalar. São Paulo: Boitempo, 2016, p. 328-329.

${ }^{29}$ Cf., a respeito do toyotismo, ANTUNES, Ricardo. Adeus ao trabalho?: ensaio sobre as metamorfoses e a centralidade do mundo do trabalho. 13ㅇe ed. São Paulo: Cortez, 2008.
} 
mente ficar off-line no aplicativo digital e outros que participaram, presencialmente, das manifestações nas ruas. ${ }^{30}$ Também foram feitas transmissões ("lives") e reuniões pelas redes sociais.

As reivindicações diziam respeito a aspectos que refletiam as condições de trabalho dos entregadores: aumento nas taxas de entrega, elevação da taxa mínima, término de bloqueios indevidos, seguro para roubos e acidentes, concessão de licença para trabalhadores contaminados na pandemia, distribuição de equipamentos de proteção individual e fim do sistema de pontuação que confere acesso a determinadas áreas de melhor remuneração. ${ }^{31}$

O nome escolhido para a mobilização foi "breque dos apps", expressão que alude às plataformas digitais que oferecem ao mercado os serviços de entrega, como iFood, Uber Eats e Rappi. A realidade enfrentada na execução das atividades de entrega levou a que os trabaIhadores de aplicativos se reunissem e se organizassem coletivamente. As dificuldades, associadas às extensas jornadas, aos riscos de acidentes, às remunerações diminutas, se acentuaram no período da pandemia. ${ }^{32}$ Para as mulheres, acrescente-se a isso a exposição frequente a práticas de assédio sexual, vindas de clientes, de representantes de estabelecimentos comerciais e também de outros entregadores. ${ }^{33}$

O "breque dos apps" conferiu visibilidade à organização de entregadores em torno de coletivos. Há, por exemplo, o Movimento dos Entregadores Antifascistas ${ }^{34}$ (que traz um elemento político à pauta de reivindicação) e a Associação dos Motofretistas de Aplicativos e Autônomos do Brasil - AMABR (criada em 1‥5.2018, em São Paulo).

Diversos coletivos têm se organizado para se transformar em cooperativas de plataformas, com o objetivo de melhorar as condições de trabalho dos entregadores. É possível citar, entre outros, os coletivos Despatronados (fundado pelos Entregadores Antifascistas do Rio de Janeiro), Señoritas Courier (coletivo de entrega por mulheres e LGBTs), Pedal Express, Buscar Express (que existe desde 1999, em Porto Alegre) e o Feme Express (de motogirls de

\footnotetext{
${ }^{30}$ Ver Folha de São Paulo de 25.7.2020 (disponível em https://www1.folha.uol.com.br/mercado/2020/07/concentracao-de-motoboys-em-segundo-breque-dos-apps-e-fraca-em-sao-paulo.shtml. Acesso em 16 nov.2020) e o site da Agência Brasil de 25.7.2020 (disponível em https://agenciabrasil.ebc.com.br/radioagencia-nacional/acervo/geral/audio/2020-07/breque-dos-apps-entregadores-paralisam-atividades-novamente-e-fazematos-no-pais/. Acesso em: 16 nov. 2020).

31 Cf. https://revistaopera.com.br/2020/07/24/breque-dos-apps-e-movimento-mais-importante-em-meses/ (acesso em 16.11.2020) e o diário Folha de São Paulo de 25.7.2020 (disponível em https://www1.foIha.uol.com.br/mercado/2020/07/concentracao-de-motoboys-em-segundo-breque-dos-apps-e-fraca-em-saopaulo.shtml. Acesso em: 16 nov.2020).

${ }^{32}$ Cf. diário El País de 25.7.2020. Disponível em https://brasil.elpais.com/brasil/2020-07-25/nossa-vida-valemais-do-que-levar-um-prato-de-comida-para-as-pessoas.html. Acesso em 16.11.2020. Ver também ABÍLIO, Ludmila Costhek; ALMEIDA, Paulo Freitas; AMORIM, Henrique; CARDOSO, Ana Claudia Moreira; FONSECA, Vanessa Patriota da; KALIL, Renan Bernardi; MACHADO, Sidnei. "Condições de trabalho de entregadores via plataforma digital durante a Covid-19". Revista Jurídica Trabalho e Desenvolvimento Humano, Campinas, Edição especial Dossiê Covid-19, 2020, p. 1-21.

${ }^{33}$ As mulheres colocaram na pauta do movimento de julho de 2020 a criação, pelas plataformas, de um canal de denúncia para as situações de assédio sexual ou estupro. Cf. https://www.pressenza.com/pt-pt/2020/08/entregadores-antifascistas-do-rio-lancam-a-plataforma-de-servicos-despatronados/. Acesso em 12 ago.2020.

$34 \mathrm{O}$ Movimento tem páginas nas redes sociais. No Facebook, pode ser acessada em https://www.facebook.com/pages/category/Personal-Blog/Entregadores-Antifascistas-107474997666913/ - acesso em: 16 nov. 2020).
} 
O Individual e o Coletivo no trabalho por plataformas digitais: possibilidades de compreensão da Constituição a partir da experiência do "breque dos apps"

São Paulo). Todos objetivam instituir uma alternativa mais justa para a execução do trabalho de entregas. ${ }^{35}$

Referindo-se ao "breque dos apps", Ruy Braga e Marco Aurélio Santana afirmam:

Olhando as reivindicações e as falas dos entregadores, percebe-se que estamos diante de um movimento por reconhecimento e dignidade no trabalho. Um tipo de movimento que busca assegurar condições mínimas de subsistência digna para os/as trabalhadores/as que, como afirmam alguns entregadores, chegam a "passar fome entregando comida". ${ }^{36}$

É possível identificar sinais de que os trabalhadores - ao menos uma parcela deles passaram a questionar o funcionamento do sistema de gestão e organização empresarial em que estão inseridos. Nas palavras de um entregador, "tem muito boy na rua, e eles [os apps] estão baixando as taxas porque sempre tem alguém para aceitar uma taxa ruim. Os aplicativos usam a nossa necessidade do momento para nos explorar". ${ }^{37}$

Para os movimentos de julho de 2020, os trabalhadores por plataformas digitais se valeram da mesma tecnologia utilizada na execução e no controle dos serviços para também se organizarem coletivamente. Aplicativos foram usados para promover reuniões on-line e coordenar as atividades do movimento. As redes sociais serviram para buscar a participação de outros entregadores e também para convencer os consumidores a aderirem e apoiarem a mobilização, pela realização de avaliações negativas das plataformas em seus próprios aplicativos e na PlayStore ou na AppStore, ou simplesmente por sua não utilização nos dias da mobilização. ${ }^{38}$

Os movimentos suscitaram reações do outro lado da relação de trabalho. Houve denúncias - discursivamente refutadas por algumas empresas, como o iFood - de práticas contrárias à manifestação dos trabalhadores, como, por exemplo, o bloqueio de entregadores com o objetivo de "dispersar o movimento" 39 , ou o incremento do valor das corridas no dia

\footnotetext{
${ }^{35}$ Ver. https://digilabour.com.br/2020/07/26/coletivos-e-cooperativas-de-entregadores-no-brasil/. Acesso em 16 nov. 2020.

${ }^{36}$ BRAGA, Ruy; SANTANA, Marco Aurélio. "\#BrequeDosApps: enfrentando o uberismo". Blog da Boitempo, 25.7.2020. Disponível em https://blogdaboitempo.com.br/2020/07/25/brequedosapps-enfrentando-o-uberismo/. Acesso em: $11 \mathrm{dez} .2020$.

${ }^{37}$ Cf. El País de 25.7.2020. Disponível em https://brasil.elpais.com/brasil/2020-07-25/nossa-vida-vale-mais-doque-levar-um-prato-de-comida-para-as-pessoas.html (destaque acrescido). Acesso em 16 nov. 2020.

38 Cf. https://www.uol.com.br/ecoa/ultimas-noticias/2020/06/29/brequedosapps-promove-mobilizacao-epede-apoio-a-greve-dos-entregadores.htm (acesso em 15 dez. 2020), https://recontaai.com.br/breque-dosapps-dicas-para-colaborar-com-a-paralisacao/ (acesso em 15 dez. 2020) e https://www.redebrasilatual.com.br/trabalho/2020/07/breque-dos-apps-greve-entregadores/ (acesso em 16 nov. 2020).

${ }^{39}$ Ver site do diário El País de 10.7.2020. Disponível em: https://brasil.elpais.com/brasil/2020-07-02/entregadores-de-aplicativos-fazem-primeira-grande-paralisacao-da-categoria-no-brasil.html. Acesso em 16 nov. 2020.
} 
da mobilização. ${ }^{40}$ Além disso, algumas plataformas digitais buscaram informar quais seriam suas "boas práticas" ou "iniciativas" com os entregadores, sobretudo em razão da pandemia. ${ }^{41}$

O "breque dos apps" revela, portanto, a organização coletiva dos trabalhadores de entrega por plataformas digitais, com reivindicações dirigidas a essas plataformas, para sua tradução em direitos e garantias. O movimento expressou, ainda, uma tomada de posição diante de alguns dilemas, a começar pelo nome. Não foi utilizada a expressão tradicional que, historicamente, designa a mobilização e a resistência coletiva dos trabalhadores, qual seja, a greve. A opção dos entregadores foi pelo termo "breque", que alude à ideia de bloqueio das entregas. ${ }^{42}$ Isso não impediu, é verdade, que parte da imprensa se referisse à mobilização como greve. ${ }^{43}$ Não obstante, a escolha representa a intenção de alcançar uma nova forma de organização e atuação coletivas.

Outro dilema diz respeito ao status jurídico dos entregadores por plataformas digitais. Não houve consenso, entre os trabalhadores, quanto a uma reivindicação de reconhecimento de vínculo de emprego - o que indica a força da ideia, sustentada pela racionalidade neoliberal, de que seriam empreendedores e autônomos. Ainda assim, a natureza das reivindicações, tipicamente trabalhistas, permitiu a compreensão de que são trabalhadores. As demandas voltadas, por exemplo, a término de bloqueios indevidos, remuneração (taxa) mínima, seguro para roubos e acidentes e fornecimento de equipamentos de proteção encontram amparo em direitos fundamentais trabalhistas previstos no art. 70 da Constituição (incisos I, IV, XXII, XXVIII).

De acordo com Renata Dutra e Ricardo Festi:

Segundo os próprios entregadores, não houve consenso na categoria quanto à postulação do reconhecimento do vínculo de emprego, eis que muitos trabalhadores valorizam a ideia de autonomia, que seria incompatível com o registro na carteira de trabalho. Embora esse dissenso revele uma dimensão subjetiva que flerta a narrativa neoliberal do trabalho autônomo, por outro lado, fica evidente que o coletivo se reconhece como trabalhadores, e não empreendedores, na medida que reivindica direitos tipicamente trabalhistas e o faz por meio do instrumento da greve. ${ }^{44}$

Aliás, as plataformas digitais, ao buscarem atender as demandas, por exemplo, de fornecimento de equipamentos de proteção individual, se aproximaram, mais explicitamente,

\footnotetext{
${ }^{40}$ Cf. DUTRA, Renata; FESTI, Ricardo. "A greve dos entregadores". Jornal GGN, 11.7.2020. Disponível em https://jornalggn.com.br/artigos/a-greve-dos-entregadores-por-renata-dutra-e-ricardo-festi/. Acesso em 16 nov.2020.

${ }^{41}$ Ver BRAGA, Ruy; SANTANA, Marco Aurélio. "\#BrequeDosApps: enfrentando o uberismo". Blog da Boitempo, 25.7.2020. Disponível em https://blogdaboitempo.com.br/2020/07/25/brequedosapps-enfrentando-o-uberismo/. Acesso em: $11 \mathrm{dez}$. 2020. Sobre as medidas noticiadas pelo iFood, pode-se consultar o site https://institucional.ifood.com.br/nossa-entrega. Acesso em 15 dez. 2020.

${ }^{42}$ Cf. BRAGA, Ruy; SANTANA, Marco Aurélio. "\#BrequeDosApps: enfrentando o uberismo”. Blog da Boitempo, 25.7.2020. Disponível em https://blogdaboitempo.com.br/2020/07/25/brequedosapps-enfrentando-o-uberismo/. Acesso em 11 dez. 2020.

${ }^{43}$ Ver, por exemplo, https://www.uol.com.br/ecoa/ultimas-noticias/2020/06/29/brequedosapps-promove-mobilizacao-e-pede-apoio-a-greve-dos-entregadores.htm (acesso em 15.12.2020)

${ }^{44}$ DUTRA, Renata; FESTI, Ricardo. "A greve dos entregadores". Jornal GGN, 11.7.2020. Disponível em https://jornalggn.com.br/artigos/a-greve-dos-entregadores-por-renata-dutra-e-ricardo-festi/. Acesso em: 16 nov. 2020 (sic).
} 
O Individual e o Coletivo no trabalho por plataformas digitais: possibilidades de compreensão da Constituição a partir da experiência do "breque dos apps"

da figura legal do empregador, que assume os riscos e as despesas da atividade econômica (art. 2ㅇ da CLT).

Mais um dilema da mobilização dos entregadores envolve a forma da organização coletiva: em vários casos, não foram constituídos sindicatos, mas associações e, principalmente, coletivos. É certo que, para a atividade de transporte de passageiros (outro serviço que tem sido bastante explorado pelas plataformas digitais), já há alguns sindicatos, como o Sindicato dos Motoristas Autônomos de Transporte Privado Individual por Aplicativos (SINDMAAP), de Brasília, ou o Sindicato dos Trabalhadores com Aplicativos de Transportes Terrestres (STATTESP), de São Paulo. ${ }^{45}$ Contudo, com relação aos entregadores por aplicativos, as notícias sobre o "breque dos apps" deram ênfase à figura dos coletivos, como os mencionados acima. Aqui também a escolha desse modo de organização coletiva, em alternativa às entidades sindicais tradicionais, aponta para a intenção, consciente ou não, de criar uma nova institucionalidade de representação para esses trabalhadores. ${ }^{46}$

Para compreender a dinâmica presente no "breque dos apps", bem como seus dilemas, é importante levar em consideração que se trata de um grupo de trabalhadores que está em processo de construção de uma identidade coletiva, de busca pelo reconhecimento de direitos e garantias e de definição dos meios e instrumentos de luta e reivindicação.

A mobilização de julho de 2020 representou uma tentativa de superar os desafios decorrentes do modelo de gestão empresarial imposto pelas plataformas digitais, no campo da organização coletiva, diante da fragmentação e da heterogeneidade das condições laborais e da valorização da lógica individualista da competição entre si. ${ }^{47}$ As decisões perante os dilemas apontados acima podem ser vistas como indicativos - ainda precários, é verdade - da constituição de novas formas de atuação e representação coletiva, diferentes das centradas em torno da figura dos sindicatos e de seus meios tradicionais de ação.

Os entregadores por plataformas digitais estão, até o momento atual, à margem do direito, tanto no âmbito individual quanto no coletivo, no sentido de que permanece em disputa a qualificação jurídica das relações contratuais firmadas com os aplicativos e as formas coletivas de organização e atuação. Cuida-se, assim, de um grupo profissional que se depara,

\footnotetext{
${ }^{45}$ Ver MACHADO, Sidnei. "Representação coletiva dos trabalhadores em plataformas digitais". CARELLI, Rodrigo de Lacerda; CAVALCANTI, Tiago Muniz; FONSECA, Vanessa Patriota da (org.). Futuro do Trabalho: os efeitos da revolução digital na sociedade. Brasília, ESMPU, 2020), p. 431-439.

${ }^{46} \mathrm{~A}$ mobilização em torno de coletivos não é uma novidade brasileira. Na França, entre julho e agosto de 2017, os entregadores da plataforma digital Deliveroo realizaram movimentos em quatro cidades (Paris, Bordeaux, Lyon e Nantes). Uma das questões em jogo era o término dos contratos com contraprestação por hora, substituídos pela plataforma por contratos com contraprestação por corrida ou entrega (que haviam começado em setembro de 2016). Os trabalhadores foram chamados a se reunir em torno de coletivos locais e realizaram piquetes de greve. Alguns dilemas identificados no "breque dos apps" também podem ser observados na mobilização francesa: os entregadores se percebem como autônomos e, portanto, não colocaram a reivindicação de reconhecimento de uma relação empregatícia, organizaram-se em torno de coletivos - como o Coletivo de Entregadores Autônomos Parisienses (CLAP) -, mas apresentaram postulações tipicamente trabalhistas, além de se expressarem na forma de uma greve. Cf. o periódico Le Monde de 26.8.2017. Disponível em https://www.lemonde.fr/economie/article/2017/08/26/en-colere-les-livreurs-de-repas-se-mobilisent-de-nouveau-pour-leursconditions-de-travail_5176952_3234.html. Acesso em 16.11.2020.

${ }^{47}$ Como observa Sidnei Machado, "a perda do sentido de pertencimento ao coletivo gera dificuldades para unificar o interesse coletivo heterogêneo e fragmentado e, também, para mobilizar e organizar de maneira eficiente a representação [coletiva]" (MACHADO, Sidnei. "Representação coletiva dos trabalhadores em plataformas digitais". CARELLI, Rodrigo de Lacerda; CAVALCANTI, Tiago Muniz; FONSECA, Vanessa Patriota da (org.). Futuro do Trabalho: os efeitos da revolução digital na sociedade. Brasília, ESMPU, 2020, p. 435).
} 
em seu horizonte, com as perspectivas e os riscos da normalização jurídica, isto é, de sua incorporação aos padrões do Direito, em especial do Direito do Trabalho. Nesse cenário, a Constituição pode oferecer algumas respostas, como será desenvolvido no próximo tópico.

\section{MOVIMENTO COLETIVO DOS TRABALHADORES DE PLATAFORMAS DIGITAIS: PERSPEC- TIVAS E RISCOS PERANTE O DIREITO E A CONSTITUIÇÃO}

Ao se refletir sobre as possibilidades abertas pelo "breque dos apps", é necessário levar em conta, de forma relacional, os planos individual e coletivo do trabalho por plataformas digitais. Assim, a discussão sobre a regulação estatal deve se desdobrar sobre esses dois planos simultaneamente.

Oliveira, Carelli e Grillo apontam quatro alternativas de respostas do Direito do Trabalho para o labor prestado por plataformas digitais. A primeira - e rejeitada de imediato pelos autores - é a de não aplicação da regulação trabalhista, de modo que as relações jurídicas entre prestadores e plataformas seriam disciplinadas pelo Direito Civil. A segunda é a incidência das normas juslaborais, mas com a necessidade de elaboração de uma nova legislação, ao fundamento de inadequação da existente. Além disso, essa alternativa sinaliza o estabelecimento de uma proteção intermediária, semelhante à parassubordinação italiana. A terceira possibilidade envolve o reconhecimento de que se cuida de uma relação laboral nova, mas todos os direitos trabalhistas devem ser garantidos, de modo similar à normativa do trabalho avulso. Por fim, a quarta opção seria a aplicação da legislação juslaboral nos exatos termos definidos na CLT, que conceitua empregado e empregador em seus artigos 20 e 30 e alude, no art. 60, à subordinação jurídica exercida por meios telemáticos ou informatizados. ${ }^{48}$

Para as "plataformas digitais puras", os autores propõem a aplicação da disciplina do trabalho avulso, com reconhecimento dos direitos laborais naquilo em que aplicáveis. ${ }^{49}$ Já no caso das "plataformas híbridas", sugerem que a legislação trabalhista atual é suficiente e adequada para a regulação dessas relações jurídicas. Afinal, classificar os trabalhadores por plataformas "como 'dependentes' ou subordinados 'telematicamente' é captar que a pequena liberdade de ativação ou desativação não altera um sistema de trabalho dirigido econômica e tecnologicamente pela plataforma". ${ }^{50}$

É importante aprofundar as perspectivas e os riscos que essas escolhas podem colocar no plano coletivo, em especial nas suas três dimensões fundamentais: a liberdade sindical, a negociação coletiva e a greve. Também é relevante pensar as respostas diante daqueles riscos, sobretudo a partir da Constituição. Trata-se de ir além da pergunta sobre a existência

\footnotetext{
${ }^{48}$ Cf. OLIVEIRA, Murilo Carvalho Sampaio; CARELLI, Rodrigo de Lacerda; GRILLO, Sayonara. “Conceito e crítica das plataformas digitais de trabalho". Revista Direito e Práxis. Rio de Janeiro, v. 11, n. 4, 2020, p. 2626-2627.

${ }^{49}$ Vale recordar que a Constituição garante a "igualdade de direitos entre o trabalhador com vínculo empregatício permanente e o trabalhador avulso" (art. 70, XXXIV).

50 OLIVEIRA, Murilo Carvalho Sampaio; CARELLI, Rodrigo de Lacerda; GRILLO, Sayonara. "Conceito e crítica das plataformas digitais de trabalho". Revista Direito e Práxis. Rio de Janeiro, v. 11, n. 4, 2020, p. 2629. No mesmo sentido, cf. CARDOSO, Ana Claudia Moreira; ARTUR, Karen; OLIVEIRA, Murilo Carvalho Sampaio. "O trabalho nas plataformas digitais: narrativas contrapostas de autonomia, subordinação, liberdade e dependência". Revista Valore, Volta Redonda, 5, 2020, p. 223-225.
} 
O Individual e o Coletivo no trabalho por plataformas digitais: possibilidades de compreensão da Constituição a partir da experiência do "breque dos apps"

ou não de vínculo de emprego nas relações de trabalho por plataformas digitais. E a experiência do "breque dos apps" pode ser produtiva nesse percurso.

Se considerarmos os sindicatos existentes, inseridos na estrutura oficial (com reconhecimento pelo Ministério do Trabalho, submissão à regra da unicidade sindical, recebimento de contribuições e possibilidade de recurso ao poder normativo da Justiça do Traba(ho) ${ }^{51}$, pode-se apontar como um desafio a essas entidades o de abarcar os trabalhadores por plataformas digitais. É a pergunta feita por Ricardo Antunes:

como organizar sindicalmente essa parcela jovem da classe trabalhadora que não se beneficiou com as conquistas sociais da época do Welfare State e que ingressa no mundo digital, às vésperas da chamada indústria 4.0, com relações de trabalho em franco processo de corrosão? ${ }^{52}$

Entretanto, na ótica dos próprios trabalhadores por plataformas digitais, abrem-se algumas questões: buscar uma forma de representação coletiva nas entidades sindicais existentes, formar uma representação coletiva que venha a se inserir na estrutura oficial ou construir uma organização coletiva fora dessa estrutura oficial?

Não obstante haja sindicatos que congregam aqueles trabalhadores, Sidnei Machado afirma que:

(...) há no Brasil iniciativas de representação e de ação coletiva, mas elas não reivindicam o modelo de representação tipicamente sindical. Embora algumas entidades tenham sido criadas como sindicatos, suas ações têm características assistenciais (caso de sindicatos e associações) ou de iniciativa de resistência e denúncias (caso dos grupos de Facebook e WhatsApp)..$^{53}$

No caso específico dos entregadores por plataformas digitais, nota-se, a partir da visibilidade conferida pelo "breque dos apps", a organização em torno de coletivos, seja para fins assistenciais, seja para fins de reivindicações laborais. Ruy Braga e Marco Aurélio Santana indicam que "o movimento está distante de uma organização sindical mais estrita" e ainda

\footnotetext{
${ }^{51}$ Sobre as características da estrutura sindical oficial, ver BOITO JR., Armando. O sindicalismo de Estado no Brasil - uma análise crítica da estrutura sindical. Campinas: Editora da Unicamp, São Paulo: Hucitec, 1991.

52 ANTUNES, Ricardo. "Trabalho digital, 'indústria 4.0' e uberização do trabalho". CARELLI, Rodrigo de Lacerda; CAVALCANTI, Tiago Muniz; FONSECA, Vanessa Patriota da (org.). Futuro do Trabalho: os efeitos da revolução digital na sociedade. Brasília, ESMPU, 2020, p. 347-356 (p. 354). Em obra anterior, o mesmo autor, ao relacionar alguns desafios fundamentais para "a revitalização dos organismos sindicais de classe", aponta de início o que seria "determinante para a sua própria sobrevivência", qual seja, "romper a enorme barreira que separa a classe trabalhadora 'estável', em franco processo de redução, dos trabalhadores e trabalhadoras intermitentes, em tempo parcial, precarizados, subempregados e desempregados, todos em significativa expansão no cenário mundial de hoje. Os sindicatos devem se empenhar fortemente na organização sindical ampliada em todos os seus setores e recortes" (ANTUNES, Ricardo. O privilégio da servidão: o novo proletariado de serviços na era digital. 1a ed. São Paulo: Boitempo, 2018, p. 294).

53 MACHADO, Sidnei. "Representação coletiva dos trabalhadores em plataformas digitais". CARELLI, Rodrigo de Lacerda; CAVALCANTI, Tiago Muniz; FONSECA, Vanessa Patriota da (org.). Futuro do Trabalho: os efeitos da revolução digital na sociedade. Brasília, ESMPU, 2020), p. 438.
} 
não é capaz, no presente momento, "de produzir um modelo de organização alternativo às formas tradicionais existentes". ${ }^{54}$

Todavia, os coletivos de entregadores, ao menos se se levar em consideração a experiência da mobilização de julho de 2020, têm semelhanças funcionais com os sindicatos. Os trabalhadores por plataformas digitais, ainda que de forma fragmentada, intermitente e numa lógica de elevada concorrência, são primeiramente integrados a uma organização empresarial, que, de modo concomitante, os dispersa na execução dos serviços, mas também os reúne na submissão ao controle algorítmico, na experiência de labor precarizado e, em última análise, nas ruas das cidades. Assim, os coletivos têm exercido, de maneira incipiente, a função sociológica dos sindicatos de "organizadores secundários", com possibilidade de abertura de caminhos para a construção de uma identidade coletiva. ${ }^{55}$

A atuação dos coletivos, como visto no "breque dos apps", também provoca à diversificação das formas tradicionais de ação sindical, mediante, por exemplo, o uso, para fins de protesto, da mesma tecnologia digital das plataformas - com apelos a que os consumidores avaliem negativamente os aplicativos ou, ainda, que deixem de utilizá-los em determinados dias, prática semelhante ao boicote -, ou o recurso às redes sociais para organização, promoção e expressão do movimento.

Pode-se, então, observar, em ato, de forma concreta, o exercício da liberdade sindical, compreendida como potência para a ação coletiva e que não se confunde com o simples direito de reunião, porque surgida historicamente a partir da luta entre as classes sociais. ${ }^{56}$ Cuida-se de liberdade garantida na Constituição (art. 8ㅇ) para as relações de trabalho em geral, ou seja, independentemente da declaração de vínculo empregatício. ${ }^{57}$

O reconhecimento de que o trabalho por plataformas digitais deve ser disciplinado pela definição jurídica de relação de emprego (artigos $2 \circ$, 3ㅇ e 6ㅇ da CLT) traz o desafio de enfrentar os limites impostos pela legislação laboral à liberdade sindical, como o regime de unicidade e a organização a partir do conceito de categoria (art. 511 da CLT), o que teria o condão de colocar obstáculos, por exemplo, para a reunião dos trabalhadores por plataformas como um todo.

Com relação à negociação coletiva, não houve, até o momento, uma reivindicação de concretização desse direito, ${ }^{58}$ nem mesmo na mobilização de julho de 2020. Os entregadores buscaram forçar e pressionar as plataformas digitais a atenderem as suas demandas, mas não foi formulada pauta específica de um canal para a negociação coletiva. Não se pode ignorar, contudo, que isso talvez esteja relacionado ao fato de que as plataformas não apresentam

\footnotetext{
54 BRAGA, Ruy; SANTANA, Marco Aurélio. "\#BrequeDosApps: enfrentando o uberismo". Blog da Boitempo, 25.7.2020. Disponivel em https://blogdaboitempo.com.br/2020/07/25/brequedosapps-enfrentando-o-uberismo/. Acesso em 11.12.2020.

${ }^{55}$ Ver OFFE, Claus e WIESENTHAL, Helmut. "Duas lógicas da ação coletiva: notas teóricas sobre a classe social e a forma de organização". OFFE, Claus. Problemas Estruturais do Estado Capitalista. Trad. de Bárbara Freitag. Rio de Janeiro: Tempo Brasileiro: 1984, p. 56-118 (p. 63-70).

${ }^{56}$ Cf. SILVA, Sayonara Grillo Coutinho Leonardo de. Relações coletivas de trabalho. São Paulo: LTr, 2008.

${ }^{57}$ Ver, em sentido semelhante, MACHADO, Sidnei. "Representação coletiva dos trabalhadores em plataformas digitais". CARELLI, Rodrigo de Lacerda; CAVALCANTI, Tiago Muniz; FONSECA, Vanessa Patriota da (org.). Futuro do Trabalho: os efeitos da revolução digital na sociedade. Brasília, ESMPU, 2020), p. 434.

${ }^{58}$ Cf. MACHADO, Sidnei. "Representação coletiva dos trabalhadores em plataformas digitais". CARELLI, Rodrigo de Lacerda; CAVALCANTI, Tiago Muniz; FONSECA, Vanessa Patriota da (org.). Futuro do Trabalho: os efeitos da revolução digital na sociedade. Brasília, ESMPU, 2020), p. 438.
} 
O Individual e o Coletivo no trabalho por plataformas digitais: possibilidades de compreensão da Constituição a partir da experiência do "breque dos apps"

uma identidade física e concreta, acessível ao público em geral e aos próprios trabalhadores em particular. As dificuldades para o estabelecimento de um canal de comunicação entre força de trabalho e plataformas digitais podem ser evidenciadas nas sanções aplicadas, como bloqueios e exclusões, com frequência sem justificativas. Esse era, a propósito, o tema de uma reivindicação presente no "breque dos apps". ${ }^{59}$

O desafio aos trabalhadores por plataformas, nesse aspecto, é superar os obstáculos da invisibilidade da empresa que opera e é encoberta pela tecnologia digital. Também aqui é possível afirmar que o direito à negociação coletiva pode ser conquistado e exercido independentemente do reconhecimento da relação de emprego. E a sua concretização estaria também amparada no texto constitucional (art. 7으, XXVI).

A terceira dimensão fundamental no campo coletivo é a greve. Como apontado acima, os entregadores optaram, na mobilização de julho de 2020, pela expressão "breque", ao invés de greve. Contudo, não se pode deixar de lado que a imagem da greve é, com frequência, associada à gestão empresarial fordista, da fábrica que reúne dentro dela, fisicamente, os trabalhadores. Além disso, deve-se levar em conta, na identificação dessa imagem, o conceito legal (art. 2ㅇ da Lei $n=7.783 / 1989$ ), que pretende restringir as potencialidades desse direito. ${ }^{60}$

Entretanto, a greve, como prática social, ${ }^{61}$ é expressão da resistência coletiva dos trabalhadores e pode assumir diferentes formas de manifestação e sentido. É o instrumento mais adequado e eficaz dos trabalhadores diante do poder do capital e, historicamente, representa meio de luta pela defesa do direito já posto, bem como para a conquista de novos direitos. ${ }^{62}$ Em seu estudo sobre as greves metalúrgicas do ABC paulista, de 1978 a 1980, Ricardo Antunes afirma que a greve manifesta "um momento de rebeldia do trabalho frente à dominação do capital". ${ }^{63}$

Uma compreensão abrangente da greve se mostra adequada e coerente com a Constituição de 1988 (art. 9), que não definiu o direito, mas estabeleceu um procedimento para o seu exercício: a escolha pelos próprios trabalhadores da oportunidade para sua deflagração

\footnotetext{
${ }^{59} \mathrm{Um}$ dos entregadores entrevistados durante o movimento afirmou: "se eu sou bloqueado, não tenho como falar com uma pessoa do iFood, eu falo com um robô". Ver o diário El País de 25.7.2020. Disponível em https://brasil.elpais.com/brasil/2020-07-25/nossa-vida-vale-mais-do-que-levar-um-prato-de-comida-para-aspessoas.html. Acesso em 16 nov. 2020.

${ }^{60}$ Cf. VIANA, Márcio Túlio. “Da greve ao boicote: os vários significados e as novas possibilidades das lutas operárias". In: DA SILVA, Alessandro; SOUTO MAIOR, Jorge Luiz; FELIPPE, Kenarik Boujikian; e SEMER, Marcelo (coordenadores.). Direitos Humanos: essência do direito do trabalho. São Paulo: LTr, 2007, p. 88-95.

${ }^{61}$ Ver PAIXÃO, Cristiano, LOURENÇO FILHO, Ricardo. "Greve como prática social: possibilidades de reconstrução do conceito a partir da Constituição de 1988". In: SENA, Adriana Goulart de, DELGADO, Gabriela Neves, e NUNES, Raquel Portugal. Dignidade humana e inclusão social: caminhos para a efetividade do direito do trabalho no Brasil. São Paulo: LTr, 2010, p. 408-424.

${ }^{62}$ Cf. VIANA, Márcio Túlio. Direito de resistência: possibilidades de autodefesa do empregado em face do empregador. São Paulo: LTr, 1996; e VIANA, Márcio Túlio. “Da greve ao boicote: os vários significados e as novas possibilidades das lutas operárias". In: DA SILVA, Alessandro; SOUTO MAIOR, Jorge Luiz; FELIPPE, Kenarik Boujikian; e SEMER, Marcelo (coordenadores.). Direitos Humanos: essência do direito do trabalho. São Paulo: LTr, 2007.

${ }^{63}$ ANTUNES, Ricardo. A rebeldia do trabalho - o confronto operário do ABC paulista: as greves de 1978/1980. 2a ed. Campinas: Unicamp, 1992, p. 189.
} 
e dos interesses a serem defendidos. ${ }^{64}$ É fundamental, portanto, entender a garantia constitucional do procedimento da greve.

Segundo Márcio Túlio Viana, pode-se falar em greve em sentido amplo para indicar protestos, denúncia ou pressão exercidos coletivamente por operários, estudantes, prostitutas, ou, mesmo para se referir a greve de fome, de palavras, de ocupação, de zelo, tartaruga, entre outros significados. Em todos esses casos, existe uma prática, que se prolonga por determinado tempo, de ruptura com a rotina. Para o direito, esse conceito de ruptura da rotina pode ser utilizado, considerando-se, porém, o contexto do trabalho. A especificidade da greve é, assim, a ruptura do cotidiano da prestação de serviços. ${ }^{65}$

Essa perspectiva mais ampla leva à conclusão de que o "breque dos apps" traduziu de fato uma greve - não por acaso, como visto, ficou evidente que os entregadores por plataformas digitais se perceberam como trabalhadores. Em atenção a determinadas reivindicações, é possível identificar contornos de uma "greve ambiental". ${ }^{66}$ De modo geral, consoante os conceitos acima, observa-se um movimento que pretendeu romper com a rotina de labor e expressar a rebeldia dos entregadores perante as plataformas.

Foi uma greve que apontou para outras potencialidades da ação coletiva dos trabaIhadores, além das formas tradicionais (como paralisações e piquetes), sobretudo em termos de comunicação entre os próprios entregadores e com a sociedade. Os movimentos de julho de 2020 colocaram no horizonte a possibilidade real e efetiva da realização de greves com a adesão do público consumidor dos serviços. ${ }^{67}$

Também nessa dimensão vale ressaltar que o exercício do direito de greve independe da declaração de existência da relação de emprego entre os trabalhadores e as plataformas digitais. A Constituição (art. 9ํ) ampara uma interpretação mais ampla desse direito, que é um desdobramento da liberdade sindical. A greve é um meio de realização da cidadania voltado à conquista e à afirmação de direitos. Nessa linha, Cristiano Paixão atribui ao "breque dos apps" uma "dimensão constituinte", no sentido de uma "luta por reconhecimento de condições mínimas de dignidade". ${ }^{68}$

Não obstante, deve-se atentar aos eventuais riscos da incorporação das manifestações coletivas dos trabalhadores por plataformas digitais aos padrões e controles estipulados

\footnotetext{
${ }^{64}$ Cf. PAIXÃO, Cristiano, LOURENÇO FILHO, Ricardo. “Greve como prática social: possibilidades de reconstrução do conceito a partir da Constituição de 1988". In: SENA, Adriana Goulart de, DELGADO, Gabriela Neves, e NUNES, Raquel Portugal. Dignidade humana e inclusão social: caminhos para a efetividade do direito do trabalho no Brasil. São Paulo: LTr, 2010.

${ }^{65}$ VIANA, Márcio Túlio. "Da greve ao boicote: os vários significados e as novas possibilidades das lutas operárias". In: DA SILVA, Alessandro; SOUTO MAIOR, Jorge Luiz; FELIPPE, Kenarik Boujikian; e SEMER, Marcelo (coordenadores.). Direitos Humanos: essência do direito do trabalho. São Paulo: LTr, 2007, p. 100-101.

66 CONFORTI, Luciana. “'Breque dos apps', greve ambiental e o 'novo normal'”. Revista Consultor Jurídico, 2.9.2020. Disponível em https://www.conjur.com.br/2020-set-02/conforti-breque-apps-greve-ambiental-normal. Acesso em 16.11.2020.

${ }^{67}$ Um exemplo interessante desse modo de ação coletiva é a flash mob. Cf., a respeito, RIBEIRO, Pedro Henrique Gonçalves de Oliveira. "Decisão Flashmob. Ação Coletiva. Direito legítimo dos trabalhadores como instrumento de pressão". Revista de Direito do Trabalho. Vol. 161, jan./fev., 2015, p. 25-39.

68 PAIXÃO, Cristiano; LOURENÇO FILHO, Ricardo. "O STF e o Direito do Trabalho: as três fases da destruição". Portal Jota, 29.6.2020. Disponível em: https://www.jota.info/opiniao-e-analise/artigos/o-stf-e-o-direito-do-trabalho-as-tres-fases-da-destruicao-29062020. Acesso em 29.6.2020.
} 
O Individual e o Coletivo no trabalho por plataformas digitais: possibilidades de compreensão da Constituição a partir da experiência do "breque dos apps"

pelo Direito. Isso pode significar, além de restrições à organização e à negociação coletivas, a imposição de limitações à greve.

A Justiça do Trabalho, principalmente pelo seu órgão de cúpula, o Tribunal Superior do Trabalho, tem construído uma jurisprudência de restrições ao direito de greve, que alcança, entre outros aspectos, o tipo de interesses que podem ser defendidos (negando, por exemplo, greves políticas) e a imposição de limites ao número de trabalhadores que participam do movimento, sobretudo nas atividades definidas em lei como essenciais. Em última análise, há uma rejeição do caráter conflitivo das relações laborais. ${ }^{69}$

Mas ainda assim o reconhecimento jurídico é importante. A greve serviu historicamente como meio de exercício de cidadania, construção e afirmação de direitos, inclusive em momentos cruciais para a democracia brasileira, ${ }^{70}$ e isso pode se mostrar verdadeiro no campo das relações laborais por aplicativos tecnológicos.

Os riscos da normalização jurídica do trabalho por plataformas digitais, sobretudo no plano coletivo, não significam, de modo algum, a opção por uma regulação estatal meramente civil ou juslaboral reduzida. Até porque a movimentação nas ruas e nas redes sociais, por parte dos trabalhadores por aplicativos, apontou para um cenário de afirmação de direitos. ${ }^{71}$ Nessa medida, a prática concreta da liberdade sindical, da negociação coletiva e do direito de greve pode servir de meio para que os trabalhadores participem de forma efetiva da discussão pública sobre a regulação jurídica do labor por plataformas, inclusive para apontar novas compreensões sobre seu modo de agir coletivamente. Também pode permitir que esses trabalhadores atuem no campo político em outros debates sobre direitos fundamentais. ${ }^{72}$

A realização material daqueles direitos constitucionais, consoante se pode constatar no "breque dos apps", provoca o pensamento jurídico a ir além do conceito de relação de emprego como requisito para o reconhecimento de garantias trabalhistas e sociais. ${ }^{73}$ Os trabalhadores por plataformas digitais, ao reivindicarem e exercerem direitos fundados na Constituição, podem sinalizar novas possibilidades para a interpretação jurídica e a concretização

\footnotetext{
${ }^{69}$ Cf. LOURENÇO FILHO, Ricardo. Entre continuidade e ruptura: uma narrativa sobre as disputas de sentido da Constituição de 1988 a partir do direito de greve. Tese de doutorado. Faculdade de Direito. Universidade de Brasília, Brasília, 2014. Partindo dessa linha de raciocínio, vale considerar que o art. 10, III, da Lei no 7.783/1989 prevê como atividade essencial a distribuição e a comercialização de medicamentos e alimentos. A pergunta que se faz é: não poderia esse dispositivo ser judicialmente aplicado para restringir a mobilização dos entregadores por plataformas digitais? Esse é um risco a ser considerado.

${ }^{70}$ Ver PAIXÃO, Cristiano, LOURENÇO FILHO, Ricardo. "Greve como prática social: possibilidades de reconstrução do conceito a partir da Constituição de 1988". In: SENA, Adriana Goulart de, DELGADO, Gabriela Neves, e NUNES, Raquel Portugal. Dignidade humana e inclusão social: caminhos para a efetividade do direito do trabalho no Brasil. São Paulo: LTr, 2010.

${ }^{71}$ Segundo José Geraldo de Sousa Júnior, "a rua (...) é o espaço público, o lugar do acontecimento, do protesto, da formação de novas sociabilidades e do estabelecimento de reconhecimentos recíprocos na ação autônoma da cidadania (autônomos: que se dão a si mesmos o direito)". Cf. SOUSA JÚNIOR, José Geraldo. Sociologia Jurídica: Condições Sociais e Possibilidades Teóricas. Porto Alegre: Sérgio Antonio Fabris Editor, 2002, p. 50.

${ }^{72} \mathrm{Em}$ análise sobre o "breque dos apps" e a possibilidade de o movimento se entrelaçar com outras lutas por direitos, Andréia Galvão observa que "a emergência de um movimento antifascista e a inclusão da democracia na pauta de uma parcela dos entregadores abre um caminho politicamente potente, pois expressa o reconhecimento de que, sem liberdades democráticas, não há direitos" (GALVÃO, Andréia. "A greve e as perspectivas do movimento dos entregadores". Jornal GGN, 14.7.2020. Disponível em https://jornalggn.com.br/a-grandecrise/a-greve-e-as-perspectivas-do-movimento-entregadores-por-andreia-galvao/. Acesso em: 1‥ Dez. 2020).

${ }^{73}$ Para uma interpretação dos direitos do art. 70 da Constituição não restrita ao vínculo de emprego, cf. PORTO, Noemia. O trabalho como categoria constitucional de inclusão. São Paulo: LTr, 2013.
} 
do texto constitucional. Futuras greves e mobilizações coletivas serão importantes. De acordo com Antunes e Filgueiras, "a capacidade de resistência, revolta e organização deste novo proletariado digital será um elemento decisivo para a conquista de formas protetivas de trabalho, capazes de obstar sua escravidão digital". ${ }^{74}$

\section{CONSIDERAÇÕES FINAIS}

Como visto neste artigo, as características do trabalho por plataformas, centrado na exploração de uma atividade econômica por meio da utilização de tecnologia digital e no incentivo ao individualismo e à concorrência recíproca entre os trabalhadores, colocam desafios significativos à sua organização coletiva. O "breque dos apps" foi relevante, entre outros motivos, porque: destacou a realidade dos entregadores por plataformas digitais (como as longas jornadas, com reduzidas remunerações, além de outros problemas); deu visibilidade aos coletivos de entregadores; e mostrou uma mobilização que utilizou a tecnologia digital para veicular suas reivindicações e seus protestos, e também para se organizar e buscar adesões, inclusive dos consumidores.

Mas a mobilização explicitou alguns dilemas, relacionados à própria denominação ("breque", e não greve); à classificação jurídica das relações de trabalho à luz da legislação juslaboral, não obstante tenham se percebido como trabalhadores; e à reunião em torno principalmente de coletivos (e não sindicatos). Esses dilemas parecem associados à circunstância de se cuidar de um grupo profissional em processo de construção de uma identidade coletiva e de afirmação de direitos e garantias.

Muito embora, em termos concretos, as reivindicações tivessem feições individuais, a mobilização foi uma tentativa de enfrentar e superar, no campo da organização coletiva, os desafios resultantes da gestão empresarial das plataformas digitais. Isso indica que a discussão sobre a regulação estatal das relações trabalhistas por aplicativos deve envolver uma análise conjunta dos planos individual e coletivo, em especial, quanto a esse último, no que toca às dimensões fundamentais da liberdade sindical, da negociação coletiva e da greve e às compreensões que os próprios trabalhadores elaboram a respeito desses direitos.

A pura e simples incorporação das relações laborais por aplicativos no conceito jurídico de vínculo de emprego pode acarretar relevantes obstáculos à mobilização coletiva dos trabalhadores por plataformas digitais. Isso não significa, contudo, que aquela incorporação deva ser rejeitada. Ao mesmo tempo, não se deve ignorar a importância do movimento coletivo no processo de construção e garantia de direitos. Conquanto seja importante, no plano individual, a regulação do Direito do Trabalho, particularmente sob o conceito de relação de emprego, é necessário reconhecer, no plano coletivo, a possibilidade constitucional de exercício, sob diversas formas, dos direitos fundamentais à liberdade sindical, à negociação coletiva e à greve, independentemente do vínculo empregatício.

No "breque dos apps", foi possível observar um conjunto de reivindicações que têm amparo constitucional, a par da inexistência, pelos entregadores, de uma pauta voltada ao

\footnotetext{
74 ANTUNES, Ricardo; FILGUEIRAS, Vitor. "Plataformas digitais, Uberização do trabalho e regulação no Capitalismo contemporâneo". Contracampo, Niterói, v. 39, n. 1, abr./jul. 2020, p. 40.
} 
reconhecimento do vínculo de emprego com as plataformas. Por meio de coletivos e da realização de greves, foram buscados direitos previstos na Constituição ou que decorrem do regime de proteção ao trabalho por ela instituído (como, por exemplo, um salário que atenda às necessidades vitais básicas e garantias à saúde). Essa constatação é provocativa no sentido de expandir a incidência dos direitos trabalhistas para além do conceito de relação de emprego, não para diminuir as garantias jurídicas e sim para seu reforço e mesmo ampliação.

Vale observar no futuro se e como os trabalhadores por aplicativos utilizarão mobilizações coletivas e principalmente greves para participar da discussão pública sobre a regulação jurídica de suas relações laborais ou mesmo se envolverem em outras lutas políticas voltadas ao reconhecimento de direitos. Para o presente, porém, é possível afirmar que o pensamento jurídico está diante do desafio de desenvolver uma compreensão mais ampla da Constituição, de modo a abranger as lutas e as reivindicações, no plano individual, e conferir sentido a direitos concretamente exercidos, no plano coletivo, relativamente ao trabalho realizado por plataformas digitais.

\section{REFERÊNCIAS}

ABÍLIO, Ludmila Costhek. "Uberização: Do empreendedorismo para o autogerenciamento subordinado". Psicoperspectivas, vol. 18, n. 3, novembro 2019, p. 1-11.

ABÍLIO, Ludmila Costhek; ALMEIDA, Paulo Freitas; AMORIM, Henrique; CARDOSO, Ana Claudia Moreira; FONSECA, Vanessa Patriota da; KALIL, Renan Bernardi; MACHADO, Sidnei. "Condições de trabalho de entregadores via plataforma digital durante a Covid-19". Revista Jurídica Trabalho e Desenvolvimento Humano, Campinas, Edição especial - Dossiê Covid-19, 2020, p. 1-21.

ANTUNES, Ricardo. A rebeldia do trabalho - o confronto operário do ABC paulista: as greves de 1978/1980. 2a ed. Campinas: Unicamp, 1992.

ANTUNES, Ricardo. Adeus ao trabalho?: ensaio sobre as metamorfoses e a centralidade do mundo do trabalho. 13ำ ed. São Paulo: Cortez, 2008.

ANTUNES, Ricardo. O privilégio da servidão: o novo proletariado de serviços na era digital. 1ạ ed. São Paulo: Boitempo, 2018.

ANTUNES, Ricardo. "Trabalho digital, 'indústria 4.0' e uberização do trabalho". CARELLI, Rodrigo de Lacerda; CAVALCANTI, Tiago Muniz; FONSECA, Vanessa Patriota da (org.). Futuro do Trabalho: os efeitos da revolução digital na sociedade. Brasília, ESMPU, 2020, p. 347-356.

ANTUNES, Ricardo; FILGUEIRAS, Vitor. "Plataformas digitais, Uberização do trabalho e regulação no Capitalismo contemporâneo". Contracampo, Niterói, v. 39, n. 1, abr./jul. 2020, p. 2743.

ARAÚJO, Maurício Azevedo de; DUTRA, Renata Queiroz; JESUS, Selma Cristina Silva de. "Neoliberalismo e flexibilização da legislação trabalhista no Brasil e na França". Revista do Direito. Trabalho e Processo. № 2, abril 2018, pp. 1-24. 
BOITO JR., Armando. O sindicalismo de Estado no Brasil - uma análise crítica da estrutura sindical. Campinas: Editora da Unicamp, São Paulo: Hucitec, 1991.

BRAGA, Ruy; SANTANA, Marco Aurélio. “\#BrequeDosApps: enfrentando o uberismo". Blog da Boitempo, 25.7.2020. Disponível em https://blogdaboitempo.com.br/2020/07/25/brequedosapps-enfrentando-o-uberismo/. Acesso em 11.12.2020.

CARDOSO, Ana Claudia Moreira; ARTUR, Karen; OLIVEIRA, Murilo Carvalho Sampaio. "O trabalho nas plataformas digitais: narrativas contrapostas de autonomia, subordinação, liberdade e dependência". Revista Valore, Volta Redonda, 5, 2020, p. 206-230.

CARELLI, Rodrigo. "O trabalho em plataformas e o vínculo de emprego: desfazendo mitos e mostrando a nudez do rei". CARELLI, Rodrigo de Lacerda; CAVALCANTI, Tiago Muniz; FONSECA, Vanessa Patriota da (org.). Futuro do Trabalho: os efeitos da revolução digital na sociedade. Brasília, ESMPU, 2020), p. 65-83.

CARVALHO NETTO, Menelick. "A hermenêutica constitucional e os desafios postos aos direitos fundamentais". SAMPAIO, José Adércio Leite (Org.). Jurisdição Constitucional e Direitos Fundamentais. Belo Horizonte: Del Rey, 2003, p. 141-163.

CHAVES JÚNIOR, José Eduardo de Resende. “O Direito do Trabalho e as Plataformas Eletrônicas". MELO, Raimundo Simão de; ROCHA, Cláudio Jannoti. Constitucionalismo, trabalho, seguridade social e as reformas trabalhista e previdenciária. São Paulo: LTr, 2017, p. 357-366.

CONFORTI, Luciana. "'Breque dos apps', greve ambiental e o 'novo normal'”. Revista Consultor Jurídico, 2.9.2020. Disponível em https://www.conjur.com.br/2020-set-02/conforti-brequeapps-greve-ambiental-normal. Acesso em 16.11.2020.

DARDOT, Pierre; LAVAL. A nova razão do mundo: ensaio sobre a sociedade neoliberal. Tradução de Mariana Echalar. São Paulo: Boitempo, 2016.

DE STEFANO, Valerio. "Labour is not a technology - Reasserting the Declaration of Philadelphia in times of platform-work and gig-economy". IUSLabor 2/2017, p. 1-17;

DUTRA, Renata; FESTI, Ricardo. “A greve dos entregadores”. Jornal GGN, 11.7.2020. Disponível em https://jornalggn.com.br/artigos/a-greve-dos-entregadores-por-renata-dutra-e-ricardofesti/. Acesso em 16.11.2020.

GALVÃO, Andréia. "A greve e as perspectivas do movimento dos entregadores". Jornal GGN, 14.7.2020. Disponível em https://jornalggn.com.br/a-grande-crise/a-greve-e-as-perspectivasdo-movimento-entregadores-por-andreia-galvao/. Acesso em 10.12.2020.

LOURENÇO FILHO, Ricardo. Entre continuidade e ruptura: uma narrativa sobre as disputas de sentido da Constituição de 1988 a partir do direito de greve. Tese de doutorado. Faculdade de Direito. Universidade de Brasília, Brasília, 2014.

MACHADO, Sidnei. "Representação coletiva dos trabalhadores em plataformas digitais". CARELLI, Rodrigo de Lacerda; CAVALCANTI, Tiago Muniz; FONSECA, Vanessa Patriota da (org.). Futuro do Trabalho: os efeitos da revolução digital na sociedade. Brasília, ESMPU, 2020), p. 431-439.

OFFE, Claus e WIESENTHAL, Helmut. "Duas lógicas da ação coletiva: notas teóricas sobre a classe social e a forma de organização". OFFE, Claus. Problemas Estruturais do Estado Capitalista. Trad. de Bárbara Freitag. Rio de Janeiro: Tempo Brasileiro: 1984, p. 56-118. 
OLIVEIRA, Murilo Carvalho Sampaio; CARELLI, Rodrigo de Lacerda; GRILLO, Sayonara. "Conceito e crítica das plataformas digitais de trabalho". Revista Direito e Práxis. Rio de Janeiro, v. 11 , n. 4, 2020, p. 2609-2634.

PAIXÃO, Cristiano, LOURENÇO FILHO, Ricardo. "Greve como prática social: possibilidades de reconstrução do conceito a partir da Constituição de 1988". In: SENA, Adriana Goulart de, DELGADO, Gabriela Neves, e NUNES, Raquel Portugal. Dignidade humana e inclusão social: caminhos para a efetividade do direito do trabalho no Brasil. São Paulo: LTr, 2010, p. 408-424.

PAIXÃO, Cristiano; LOURENÇO FILHO, Ricardo. "O STF e o Direito do Trabalho: as três fases da destruição". Portal Jota, 29.6.2020. Disponível em: https://www.jota.info/opiniao-e-analise/artigos/o-stf-e-o-direito-do-trabalho-as-tres-fases-da-destruicao-29062020. Acesso em 29.6.2020.

PORTO, Noemia. O trabalho como categoria constitucional de inclusão. São Paulo: LTr, 2013;

RIBEIRO, Pedro Henrique Gonçalves de Oliveira. "Decisão Flashmob. Ação Coletiva. Direito legítimo dos trabalhadores como instrumento de pressão". Revista de Direito do Trabalho. Vol. 161, jan./fev., 2015, p. 25-39.

SILVA, Sayonara Grillo Coutinho Leonardo de. Relações coletivas de trabalho. São Paulo: LTr, 2008.

SOUSA JÚNIOR, José Geraldo. Sociologia Jurídica: Condições Sociais e Possibilidades Teóricas. Porto Alegre: Sérgio Antonio Fabris Editor, 2002.

VIANA, Márcio Túlio. Direito de resistência: possibilidades de autodefesa do empregado em face do empregador. São Paulo: LTr, 1996.

VIANA, Márcio Túlio. "Da greve ao boicote: os vários significados e as novas possibilidades das lutas operárias". In: DA SILVA, Alessandro; SOUTO MAIOR, Jorge Luiz; FELIPPE, Kenarik Boujikian; e SEMER, Marcelo (coordenadores.). Direitos Humanos: essência do direito do trabalho. São Paulo: LTr, 2007, p. 88-95.

ZAGREBELSKY, Gustavo. Historia y constitución. Tradução de Miguel Carbonell. Madrid: Minima Trotta, 2005. 